Doi: HTTPS://DOI.ORG/10.23910/2/2020.0371

\title{
Women Empowerment in Agriculture and its Dimensions: A Conceptual Review
}

\author{
Deepika Sharma*, Rashmi Chaudhary and Krishan Kumar
}

Department of Business Management, College of Horticulture, Dr. Y. S. Parmar University of Horticulture and Forestry, Nauni, Solan, Himachal Pradesh (173 230), India

\section{Corresponding Author}

Deepika Sharma

e-mail: deepikasharma_07@yahoo.co.in

\author{
Article History \\ Article ID: IJEP0371 \\ Received in $28^{\text {th }}$ March, 2020 \\ Received in revised form $26^{\text {th }}$ May, 2020 \\ Accepted in final form $08^{\text {th }}$ June, 2020
}

\begin{abstract}
Women empowerment is a broader term which has been described in a variety of ways. It is a global issue, which has been accelerated in recent decades. The term women empowerment has also received much attention from researchers, government and other stakeholders. It is now widely accepted that gender equality and women empowerment are essential component for achieving development results. The present article is an attempt to develop conceptual clarity of the term women empowerment and its dimensions in agriculture. As per the existing literature it has been reviewed that women empowerment is a complex and multidimensional concept. Different dimensions of women empowerment resulting from various definitions are: input in productive decisions and autonomy in production, ownership of assets and access to and decisions on credit, control over use of income, workload and time allocation and education. It has also been analysed that access to these dimensions and women empowerment might lead toward sustainable development in terms of improved livelihood resulting in reducing food insecurity.
\end{abstract}

Keywords: Asset ownership, credit access, decision making, dimensions, empowerment, workload

\section{Women Empowerment}

Empowerment is a multi level construction which refers to individuals, organizations and community. Empowerment involves mutual respect, critical reflection, caring and group participation, through which people gain greater access to and control over these resources.

Literally empowerment means the act of granting power, right, or authority to someone or something to perform various acts or duties. It is the state of being empowered to do something. Through empowerment individuals acquire the power to think and act freely, exercise choice and fulfill their potential as full and equal members of society.

There is no single definition of women's empowerment in the literature. As per different studies the term empowerment is associated with autonomy, freedom, ownership of and control over assets, agency, collective action, power and its redistribution, self-determination, participation, dignity, social inclusion, and choice (Kabeer, 1999; Malhotra and Schuler, 2002; Alsop et al., 2006; Ibrahim and Alkire, 2007; Samman and Santos, 2009 ). Bold et al. (2013) summarized those women empowerment refers to choice, power, options, control, and agency. Women empowerment is a situation in which women are given the opportunity to participate fully in social, political and economic spheres of life (Sushama, 1998). Through women empowerment women move from the state of being oppressed to the state in which both the oppressor and the oppressed are socially, politically and economically equal. (Chattopadhyay, 2005).

Gender equality, is another form of women empowerment. This means removing those obstacles that hinder women from participating in commerce, education, politics and culture and according them equal of opportunities (Backhams, 2007). Various studies have reported that gender equality is addressed by giving women more access to land, credit market and labour opportunities (Morrison and Biehl, 2007). It has also been revealed through the different studies that gender equality correlates highly with economic growth. A positive relationship has been found between gender inequality and low per capita income. It is also argued that there is an inverse relationship between gender inequality and low government expenditure on education (Morrison and Biehl, 2007). According to Luke (1974) the concept of power in women empowerment helps researchers, academics and policymakers to examine the underlying social and cultural structures that define gender relations. 


\section{Women Empowerment and Agriculture}

Women also play a significant role in the sustainable development of the economy through their contribution in the household and agricultural activities, often at par with men (Majumdar and Shah, 2017). IFAD (2011) reported that women empowerment in agriculture is one of the most important dimensions of empowerment for rural women. Women play crucial roles as farmers and business women in smallholder agricultural production. Simultaneously they manage household nutrition as mothers (Abebe et al., 2016). Women make up to half of the agricultural labour force in many developing countries; however the nature and extent of men and women farmers' role vary from region to region, culture to culture, even from crop to crop. Along with active participation of women in agriculture they are responsible for most household activities, like food preparation, fetching water, firewood collection, and child care due to the gender based division of labour. (Singh and Arora, 2010). Women's empowerment has a direct impact on agricultural productivity and household food security (Sraboni et al., 2014; Harper et al., 2013). A women who is empowered to make decisions regarding what to plant and what inputs to apply on her plot will be more productive in agriculture. Empowered women will also be better able to ensure her children's health and nutrition, in no small part because she is able to take care of her own physical and mental well-being (Smith et al., 2003). Experts say that if the gender gap is reduced in access of productive resources and opportunities and women are provided these basic services then agriculture productivity could grow by $20-25 \%$ to meet food security and may reduce hunger (Srivastava and Srivastava, 2017). Since women in rural areas are largely dependent on agriculture for their livelihoods, household's vulnerability to food insecurity is greatly influenced by their levels of empowerment in agriculture (IFAD, 2011).

\section{Dimensions of Women Empowerment in Agriculture}

Women's empowerment is a complex and multidimensional concept. Different dimensions of women empowerment resulting from various definitions of women empowerment are: input in productive decisions and autonomy in production (Unnati et al., 2012 ; Alkire et al., 2013; Das, 2015; Jha and Nagar, 2015; Malapit et al., 2015; Khyade and Khyade, 2016), ownership of assets and access to and decisions on credit (Mazhawidza and Mangengwa, 2011; Isa, 2012; Alkire et al.,2013; Jha and Nagar, 2015 ; Malapit et al., 2015; Srivastava and Srivastava, 2017), control over use of income (Mehra and Rojas, 2008; Jha and Nagar, 2015; Malapit et al., 2015; Srivastava and Srivastava, 2017), Group membership (FAO, 2011; Alkire et al., 2013; Gupta et al., 2017) Workload and time allocation (Narayan, 2002; Alkire et al., 2013; Malapit et al., 2015; Srivastava and Srivastava, 2017).

3.1. Input in productive decisions and autonomy in production

This dimension concerns decisions about agricultural production. It refers to sole or joint decision-making about food and cash crop farming, livestock and fisheries, and autonomy in agricultural production (Alkire et al., 2013).

The women play a significant and crucial role in agricultural development and allied activities including crop production, livestock rearing, horticulture production, post harvest activities, agro forestry, fisheries etc. Women work in the fields, homes, outside the farm, and at the markets, but decisions over the household and its economy are often dictated by their male counterparts. While taking decisions pertaining to agricultural sector, women's suggestions are not given due consideration. Women have less authority than men to productive decision making. This is one of the reasons for inequality in gender (Das, 2015; Jha and Nagar, 2015; Khyade and Khyade, 2016). The involvement of farm women in decision making is a tool for achieving greater success towards economically and ecologically sustainable agriculture. Although men take an active role in decision making in different areas of agriculture; still age, education and annual income are positively and significantly correlated to the participation of women in farm decision-making (Unnati et al., 2012).

\subsection{Control over use of income}

This dimension concerns about control over the use of income and expenditures whether sole or joint. A person is considered adequate on this dimension if he or she has input and participation into decisions related to the activity about generated income (Alkire et al., 2013).

The man is the sole decision maker related to income in the family. An example is that a woman cannot even sell her own livestock. Her husband is the one who authorized that and who sells it (Bagayoko, 2018). As the farm produce is marketed commonly by men and that gives them complete control over household finance (Patel, 2012). Mahmud et al. (2012) has confined through his studies that doing work and income-generating activities successfully empowers not just an individual but empowers the entire family too.

\subsection{Access to and decision on credit}

Credit is the most crucial input. The access of women to the credit is limited since they are not the land owners. If women do not own land, they have little access to credit; because credit facility requires collateral such as ownership of land. Little access to credit result in low agricultural productivity as without credit women find it difficult to purchase essential inputs such as seeds, tools and fertilizer (Mazhawidza and Mangengwa, 2011; Srivastava and Srivastava, 2017). A large disparity exists between men and women in terms of accessing banking services. Due to low levels of property ownership, women often lack land ownership as a collateral for bank loans. Even micro-credit schemes have come under scrutiny for coercive lending practices (Jha and Nagar, 2015).A significant positive relationship has been observed between 
rural women's access to agricultural credit and its effect on agricultural productivity. Isa (2012) has revealed through her study that there is a significant correlation between credit and output. It has also been opined that women who received a substantial amount of credit also produced higher agricultural output (Isa, 2012).

\subsection{Work load and time allocation}

Time allocation dimension concerns the allocation of time to productive and other household activities. It also involves satisfaction with the time available for leisure activities (Alkire et al., 2013). Women's time constraints not only are a burden on women themselves but can negatively affect the care and welfare of children and other family members as well (Narayan, 2002) .

Women perform rigorous agricultural work that is undervalued and underpaid. As farmers, agricultural workers and entrepreneurs, women constitute the backbone of India's agricultural and rural economy. Their hard work has not only been unpaid but also remained mostly unrecognized. They perform on a daily basis the most tedious and back-breaking tasks in agriculture, animal husbandry and homes. They are also responsible for the well-being of the household. They care for their children, provide nutrition or usually take part in agricultural activities, and complete domestic tasks. (Patel, 2012; Srivastava and Srivastava, 2017).

\subsection{Education}

Education is most important means of empowering women. Education enhances women with the knowledge, skills and self confidence to participate fully in the development process. If the women are educated then the economy will also be improved. Education helps them to grab more number of opportunities and become stronger and powerful than earlier. It will also lead to reduce the poverty levels and improve in the economic growth (Bhoganadam et al., 2014).

Majority of Indian women engaged in agriculture are illiterate. Illiteracy prevents women from participating in more skilled labor sectors. Due to this factor average gender wage disparity exists. The lack of employment mobility and education render the majority of women in India vulnerable (Srivastava and Srivastava, 2017).

\subsection{Ownership of assets}

Although women have equal rights under the law to own property and receive equal inheritance rights, yet in practice, women are at a disadvantage. The Hindu Succession Act of 2005 provides equal inheritance rights to ancestral and jointly owned family property. Due to the strong patriarchal custom in India men hold authority over female family members and inherit property and title. Due to weak enforcement of law most of the women do not get a share of parental property, and do not own any property in their own names. Women continue to have little access to land and property due to weak enforcement of laws protecting them (Jha and Nagar, 2015).
Women hardly enjoy property's ownership rights directly in their names. They face constraints in accessibility to land. Women have little control over decisions made in reference to land. Women face significant obstacles in agriculture, especially inequalities in access to and control over crucial resources and inputs, even with land in their names (Srivastava and Srivastava, 2017; Mehra and Rojas, 2008). Even FAO (2011) states that in countries such as Latin America where there is greater access to land, men have larger land holdings as compare to women.

\section{Conclusion}

Women, the integral part of society, play a significant role in sustainable development of economy through their household and other activities. Still they are ignored; face discrimination and many obstacles in every aspect of life. Empowering women is the pivotal role in the empowerment of family and society as well. Women empowerment would lead toward improving livelihood by reducing food insecurity because they can spend more on their families. Women must have financial liberty and role in decision making.

\section{References}

Abebe, L., Kifle, D., Groot, H.D., 2016. Analysis of women in agriculture index: the case study of Toke Kutaye District of Oromia, Ethiopia. In: Proceedings of $5^{\text {th }}$ International Conference of African Association of Agricultural Economists, Ethiopia, 23-26.

Alkire, S., Dick, R.M., Peterman, A., Quisumbing, A.R., Seymour, G., Vaz, A., 2013. The women's empowerment in agriculture index, World Development 52, 71-91.

Alsop, R., Bertelsen, M., Holland, J., 2006. Empowerment in practice from analysis to implementation, Washington, DC: World Bank, https:// openknowledge.worldbank.org/handle/10986/6980.

Backhams, M.C., 2007. Does increased gender equality lead to convergence of health outcomes for men and women? A study of Swedish Municipalities. Swedish National Institute of Public Health. Social Science and Medicine 64(9), 892-903.

Bagayoko, M.L., 2018. Mali home gardens qualitative gender study. The World Vegetable Center, Unpublished report.

Bhoganadam, S.D. , Malini, H, Rao, D.S., 2014. Women's empowerment and economic development. International Journal of Multidisciplinary Management Studies 4(8), 100-107.

Chattopadhyay, A., 2005. Women and entrepreneurship. Yojana, a Monthly Journal of Ministry of Information and Broadcasting 5(1), 123-156.

Das, L., 2015. Work participation of women in agriculture in Odisha. IOSR Journal of Humanities and Social Science 20, 66-78.

FAO, 2011. Women in agriculture: Closing the gender gap for development. In: The state of food and agriculture. 
Rome.

Gupta, S., Pingali, P.L., Andersen, P.P., 2017. Women's empowerment in Indian agriculture: does market orientation of farming systems matter? Food Security 9, 1447-1463.

Harper, S., Zeller, D., Hauzer, M., Pauly, D., Sumaila U.R., 2013. Women and fisheries: contribution to food security and local economies. Marine Policy 39, 56-63.

Ibrahim, S., Alkire, S., 2007. Agency and empowerment: a proposal for internationally comparable indicators. Oxford Development Studies 35(4), 379-403.

IFAD, 2011. Women and rural development. Rural Poverty Report, Rome, 378.

Isa, G.H., 2012. Accessibility of formal source of credit by rural women and the implication on Nigeria agricultural output: Case study of Jema'a and Kaura Local Government Area of Kaduna State. Journal of Agriculture and Veterinary Sciences 4, 23-33.

Jha, P., Nagar, N., 2015. A study of gender inequality in India. The International Journal of Indian Psychology 2, 1-8.

Kabeer, N., 1999. Resources, agency, achievements: reflections on the measurement of women's empowerment. Development and Change 30, 435-464.

Khyade, V.B., Khyade, S.V., 2016. Indian women in agriculture. International Academic Journal of Social Sciences 3, 1-8.

Luke, S., 1974. Power : a radical view.: Macmillan Press, London ,New York, 64.

Mahmud, S., Shah, N.M., Becker, S., 2012. Measurement of women's empowerment in rural Bangladesh. World Development 40(3), 610-619.

Majumdar, J., Shah, P., 2017. Mapping the role of women in agriculture. Annals of Anthropological Practice 41, 46-54.

Malapit, H., Kovarik, C., Sproule, K., Dick R. M., Quisumbing A., 2015. Instructional guide on the abbreviated women's empowerment in agriculture index (A-WEAI). Available from https://www.ifpri.org/sites/default/files/Basic\%20 Page/weai_instructionalguide.

Malhotra, A., Schuler, S.R., 2005. Women's empowerment as a variable in international development. In measuring empowerment: cross-disciplinary perspectives, Washington, DC: World Bank, 219-246.

Mazhawidza, P., Manjengwa, J., 2011. Research Report: The social, political and economic transformative impact of the fast track land reform programme on the lives of women farmers in Goromonzi and Vungu-Gweru Districts of Zimbabwe. Available from http://www. landcoalition.org/sites/default/files/publication/958/ WLR_8_Zimbabwe pdf.

Mehra, R., Rojas, M.H., 2008. Women, food security and agriculture in a global marketplace. International Center for Research on Women, www.fao.org/focus/e/women/ sustin- e.htm.

Morrison, A., Biehl, L., 2007 . Too close to home: domestic violence in Latin America. Washington, D.C.: InterAmerican Development Bank.

Narayan, D., 2002. Empowerment and poverty reduction: A sourcebook. World Bank Publications, Washington, DC, https://openknowledge.worldbank.org/ handle/10986/15239.

Patel, A., 2012. Empowering women in agriculture. Yojana 56, 19-22.

Samman, E., Santos, M.E., 2009. Agency and empowerment: a review of concepts, indicators and empirical evidence, Oxford, UK.. Available from www.ophi.org.uk/wpcontent/uploads/OPHI-RP-10a.pdf.

Singh, S., Arora, R., 2010. Ergonomic intervention for preventing musculoskeletal disorders among farm women. Journal of Agricultural Sciences 1(2), 61-71.

Smith, L.C., Ramakrishnan, U., Ndiaye, A., Haddad, L., Martorell, R., 2003. The importance of women's satus for child nutrition in developing countries. Research Report 131, Washington, DC: International Food Policy Research Institute. Available from www.ifpri.org/sites/ default/ files/publications/rr131.pdf.

Sraboni, E., Malapit, H.J., Quisumbing, A.R., Ahmed, A,U., 2014. Women's empowerment in agriculture: What role for food security in Bangladesh? World Development 61, 11-52.

Srivastava, S.P., Srivastava, S.P., 2017. Role of women in Indian agriculture-Issues and challenges. Journal of Agroecology and Natural Resource Management 4, 37-43.

Sushama, S., 1998. Women and Empowerment-Approach and Strategies, Discovery Publishing House, Delhi.

Unnati, A., Ankush ,G.S., Mande, J.V., 2012. Extent of participation of farm women in decision making. Journal of Dairying, Foods and Home Sciences 31, 72-74.

Bold, M.V.D., Quisumbing, A.R., Gillespie, S., 2013. Women's empowerment and nutrition: an evidence review. IFPRI discussion Paper. International Food Policy Research Institute. Available from http://www.ifpri.org/sites/ default/files/publications/ ifpridp01294.pdf. 